Published in final edited form as:

Clin Gastroenterol Hepatol. 2015 September ; 13(9): 1702. doi:10.1016/j.cgh.2015.05.008.

\title{
Response to letter to the editor by Rokutan
}

\author{
W. Asher Wolf, MD, MPH ${ }^{1,2}$ and Evan S. Dellon, MD, MPH ${ }^{1,2}$ \\ ${ }^{1}$ Center for Esophageal Diseases and Swallowing, Division of Gastroenterology and Hepatology, \\ Department of Medicine, University of North Carolina School of Medicine, Chapel Hill, NC \\ ${ }^{2}$ Center for Gastrointestinal Biology and Disease, Division of Gastroenterology and Hepatology, \\ Department of Medicine, University of North Carolina School of Medicine, Chapel Hill, NC
}

\begin{abstract}
We thank Dr. Rokutan for the interest in our recent paper $^{1}$ and for raising the important issue about therapeutic endpoints in EoE. There is as yet no consensus on the most appropriate endpoint of EoE treatment, ${ }^{2}$ and in addition to histologic response, symptoms, endoscopic findings, esophageal remodeling, and quality of life have all been proposed. ${ }^{3} \mathrm{We}$ chose to focus on histologic response for this study because it is objective and readily quantifiable, but we agree that symptom response is important as well. It has only been recently that validated symptom instruments in EoE have become available, ${ }^{4,5}$ and we could not employ these due to the retrospective cohort design of our study.
\end{abstract}

Symptomatic and histologic responses may not correlate in EoE, a finding that has been noted in several previous clinical trials. ${ }^{2}$ Potential explanations for improved symptoms despite histologic non-response include esophageal dilation at baseline, dietary modification or food avoidance, and a decrease in eosinophil count that does not reach the empirically chosen response threshold. In our study we could not investigate the specific reasons for the gap between symptomatic and histologic response, but this is an active area of investigation. ${ }^{6}$ We were able to reassess baseline immunohistochemical staining as a predictor of symptom response. While there was a trend for increased tryptase staining in symptom responders compared to non-responders (median 199 vs 153 cells $/ \mathrm{mm}^{2} ; \mathrm{p}=0.08$ ), this was not seen for major basic protein ( 1460 vs 1363 ; $\mathrm{p}=0.89$ ) or eotaxin-3 (786 vs 204; $\mathrm{p}=0.13$ ). However, given that only a subset of the study subjects had this staining performed, this should be studied prospectively in a larger sample. We agree with Dr. Rokutan that understanding discordance between histologic, symptomatic, and other treatment outcomes in EoE is of importance, and we and others are pursuing this area of research.

\section{References}

1. Wolf WA, Cotton CC, Green DJ, Hughes JT, Woosley JT, Shaheen NJ, Dellon ES. Steroid therapy for eosinophilic esophagitis: Predictors of response and treatment of steroid-refractory patients. Clin Gastroenterol Hepatol. 2015; 13:452-8. [PubMed: 25086190]

2. Dellon ES, Liacouras CA. Advances in Clinical Management of Eosinophilic Esophagitis. Gastroenterology. 2014; 147:1238-1254. [PubMed: 25109885]

Corresponding Author: Evan S. Dellon MD, CB\#7080, 4140 Bioinformatics Building, 130 Mason Farm Rd., UNC-CH, Chapel Hill, NC 27599-7080, Phone: (919) 966-2513, Fax: (919) 843-2508, edellon@med.unc.edu. 
3. Hirano I. Therapeutic End Points in Eosinophilic Esophagitis: Is Elimination of Esophageal Eosinophils Enough? Clin Gastroenterol Hepatol. 2012; 10:750-2. [PubMed: 22366179]

4. Dellon ES, Irani AM, Hill MR, Hirano I. Development and field testing of a novel patient-reported outcome measure of dysphagia in patients with eosinophilic esophagitis. Aliment Pharmacol Ther. 2013; 38:634-42. [PubMed: 23837796]

5. Schoepfer AM, Straumann A, Panczak R, Coslovsky M, Kuehni CE, Maurer E, Haas NA, Romero Y, Hirano I, Alexander JA, Gonsalves N, Furuta GT, Dellon ES, Leung J, Collins MH, Bussmann C, Netzer P, Gupta SK, Aceves SS, Chehade M, Moawad FJ, Enders FT, Yost KJ, Taft TH, Kern E, Zwahlen M, Safroneeva E. Development and validation of a symptom-based activity index for adults with eosinophilic esophagitis. Gastroenterology. 2014; 147:1255-66e21. [PubMed: 25160980]

6. Green DJ, Wolf WA, Hughes JT, Cotton CC, Woosley JT, Shaheen NJ, Dellon ES. Most patients demonstrate correlation between symptoms, endoscopic findings, and histology in response to topical steroid treatment in eosinophilic esophagitis. Gastroenterology. 2014; 146(Suppl 1):1840. Ab Mo. 